\title{
School Climate and Organizational Commitment of Mindanao State University Feeder High School Teachers: Basis for Improvement
}

\author{
Lotis A. Baoc-Daguisonan \\ Department of Secondary Teaching, College of Education \\ Mindanao State University, Philippines \\ daguisonanl@gmail.com
}

\begin{abstract}
The study determined the school climate and organizational commitment of teachers in MSU-UTC and MSU-ILS in Lanao del Sur during the school year 2014-2015. It described the teachers' assessment of their school climate in terms of supportive behavior; engaged teacher behavior; frustrated teacher behavior; and intimate teacher behavior; as well as their organizational commitment in terms of affective; continuance; and normative commitment. The study made used of the descriptive-correlational research method; and involved 145 participants. The data were gathered through an adopted-modified Organizational Commitment Description Questionnaire (OCDQ) and Organizational Commitment Questionnaire (OCQ) which were supplemented through a focus group discussion. Mean, standard deviation, and Pearson Product Moment Correlation were used to analyze and interpret the data of the study. The findings showed a very high degree of openness on school climate in terms of supportive principal behavior; engaged teacher behavior; and intimate teacher behavior. Moreover, the findings showed that the MSU feeder high schools teachers were all of the times committed to their schools in terms of affective commitment. Finally, MSU feeder high school climate was significantly correlated to teachers' organizational commitment. Hence, it is concluded that MSU feeder high schools are institutions characterized as having conducive working-learning environment for both teachers and students.
\end{abstract}

Keywords: school climate, organizational climate, feeder high schools

\section{INTRODUCTION}

School climate is a critical component of effective schools. It is thought to represent the attitude of an organization which influences the quality of instruction. A healthy school climate provides teachers a means in which they believe in themselves and set high goals for their students. A happy teacher is considered a better teacher. If happy people truly perform better, then leaders must create conditions in which happiness thrives. A school with a positive climate for teachers is more likely to have committed teachers (Smith, 2009).

School climate influence the level of commitment of teachers. Teachers receiving administrative support are more likely to be committed to the school's goals and values. Since, teacher commitment influence student achievement, creating a positive school climate can become an effective means for improving student performance (Gruenert, 2008). Hence, commitment is associated with the quality of life in the organization.

Teaching is a profession so concerned about commitment. The quality of education depends mainly on the commitment of teachers who guide and carry most of the tasks and activities of education. Organizational commitment consists of the factors such as the teacher's beliefs and acceptance of the school's goals and values; their willingness to exert effort on behalf of the school; and a strong desire to keep up membership in the school. Consequently, the factors influencing the level of commitment of teachers in schools and in wider education systems must be given focus in researches that will lead to the introduction of reforms and changes within schools (Razak, Darmawan, Keeves, 2009).

School climate and teacher commitment are vital to school success. Just like any educational institution, the Mindanao State University in Marawi
City, Philippines envisions to provide quality education for Mindanao's poor. However, like other State Universities and Colleges, MSU is confronted by similar problems such as poor education spending and annual budget cutbacks. With poor finances, MSU is confronted with problems on meeting its basic academic needs like laboratory facilities and library resources which brought frustrations to both teachers and students. Issues on lack of school facilities and insufficient administrative support pose a great challenge to MSU in providing a framework within which all students, teachers, and administrators in feeder high schools can function cooperatively and productively towards the realization of their educational goals.

Open climate feeder high schools are needed if MSU wish to provide students with a harmonious place for a maximized learning endeavor. In the same manner, teachers must be committed and dedicated in doing their duties and responsibilities so that students would become competitive and better prepared for higher education. Having no opportunities to acquire higher education, these young people in Marawi City might be tempted to go into wayward pursuits.

\section{LITERATURE REVIEW}

This study is anchored on the concept of Hoy and Miskel (1991) that school climate is the heart and soul of the school; the psychological and institutional attributes that gives a school its personality. It is a set of internal characteristics that distinguishes one organization from another. Thus, school climate is a relatively enduring quality of the school environment that is experienced by participants, affects their behavior, and is based on their collective perceptions of behavior in schools.

Moreover, this study is anchored on the concept of Allen and Meyer, (1990) that commitment 
is a force that binds an individual to a course of action of relevance to one or more targets. Along with climate, organizational commitment is also a critical component of effective schools. With its emphasis on attachment, commitment goes beyond loyalty to a school; it involves giving of one's self to the school.

Furthermore, Smith (2009) theorized that school climate influence the teachers' commitment. A school with a positive climate for teachers is more likely to have committed teachers. The association between school climate and commitment shows that teachers who are provided with the resources, protected from intrusions, and receive administrative support are more likely to be committed to the schools goals and values. Teacher commitment is also greater in schools characterized by high levels of teacher collegiality, professional influence, and positive student behavior. Schools built around these variables are likely to have teachers who are more committed to the profession and to the goals and values of their schools.

Certain types of climates exist in the school system such as open; autonomous; controlled; familiar; paternal; and close. Hoy and Sabo (1998) describe the open climate as supportive, authentic, and most likely to bring about organizational change. Teachers working in an open climate are more apt to go the extra mile and work for organizational success. An open school climate is characterized by teacher relations that are professional, collegial, friendly, and committed to the education of students. The principal is supportive and does not restrict or direct teachers with orders (Hoy, 2003).

Supportive principal behavior is characterized by efforts of school principal to motivate teachers by using constructive criticism and setting as an example through hard work. At the same time, the principal is helpful and genuinely concerned with the personal and professional welfare of teachers. Supportive behavior is directed toward both the social needs and task achievement of the faculty (Hoy, 2003).The principal listens and is open to teacher suggestions. The competence of the faculty is respected; praise is given genuinely and frequently, and criticism is handled constructively.

Moreover, engaged teacher behavior is characterized by high faculty morale. Teachers are proud of their school, enjoy working with each other, and are supportive of their colleagues. Teachers are not only concerned about each other; they are committed to the success of their students. They are friendly with students, trust students, and are optimistic about the ability of students to succeed (Hoy, 2003). Hence, engaged teacher behavior characterizes teachers with desirable attitudes as manifested by their strong commitment of providing quality education to their students; and maintaining wholesome relationship with their peers and superiors.

In addition, frustrated teacher behavior refers to a general pattern of interference from both administration and colleagues that distracts the basic task of teaching. Routine duties, administrative paperwork, and assigned nonteaching duties are excessive. Teachers irritate, annoy, and interrupt each other (Hoy, 2003). They also tend to be indifferent or even divisive, intolerant and uncommitted. Teachers do not exercise cooperative efforts and participation in school activities; do not welcome criticisms and suggestions from colleagues; and do not receive due recognition for their hardwork in school.

Furthermore, intimate teacher behavior reflects a strong and cohesive network of social relationships among the faculty. Teachers know each other well, are close personal friends, and regularly socialize together (Hoy, 2003).This type of behavior is reflected among teachers who value the quality of their interpersonal relationship with peers and superiors. Teachers maintain wholesome and cordial relations with colleagues; are happy and proud of the achievements of other faculty members; have a mutual trust and respect with other teachers; and offer help and assistance to their colleagues when needed.

On the other hand, affective commitment reflects commitment based on emotional ties the teachers develop with the school primarily via positive work experiences. It refers to their emotional attachment, identification with, and involvement in the organization. Meyer and Allen (1990) theorized affective commitment as the "desire" component of organizational commitment. Affection for teaching occurs when teachers feel a strong emotional attachment to their school, and to the work that they do. They are happy to work in their schools until retirement; have a strong sense of belonging to their schools; and are willing to render extra services even without remuneration.

Moreover, continuance commitment reflects commitment based on the perceived costs, both economic and social, of leaving the organization. It refers to teachers' assessment of whether the costs of leaving the school are greater than the costs of staying. This type of commitment occurs when teachers weigh up the pros and cons of leaving their schools. Allen and Meyer (1990) theorized that continuance commitment is the "need" component or the gains versus losses of working in an organization. These perceived losses, or side bets, can be monetary (teachers might lose salary and benefits); professional (teachers might lose seniority or role-related skills that they've spent years acquiring); or social (teachers lose friendships or allies).The severity of these losses often increases with age and experience. Thus, continuance commitment is shown among teachers who choose to stay in the profession for economic reason as merely having a stable source of income to support the needs of the family. At any rate, it is the threat of loss that commits the teachers to the schools they are working at.

In addition, normative commitment reflects commitment based on perceived obligation towards the organization. It is the degree in which teachers feel obligated to the school or believe that staying in the school is the right thing to do. Allen and Meyer (1990) theorized normative commitment as the "obligation" component of organizational commitment. This type of commitment occurs when teachers, although unhappy in their jobs; or even if they want to pursue better opportunities feel a sense of obligation to stay with the 
school because it's the right thing to do. This sense of obligation can stem from several factors such as the feeling that they should remain with the school because it has invested money or time for their training. Teachers might also choose to stay in their job out of their sense of duty towards the profession they have chosen.

The three components of commitment are not mutually exclusive. One can experience all three, or two of the three, in varying degrees (Allen and Meyer, 1990). Some teachers, for example, will likely experience continuance commitment at some point in their careers; because they'll feel that they need to stay in their job to receive pay and benefits. And some people will likely feel a sense of normative commitment if their organization has invested a lot in their training and development. However, school administrators must desire to grow affective commitment, and reduce teachers' reliance on continuance and normative commitment.

\section{METHODS}

This study made used of descriptivecorrelational method of research. Correlational research involves collecting data in order to determine the degree to which a relationship exists between two or more variables. In this study, the degree of relationship between school climate and organizational commitment was determined. The study was conducted in three MSU feeder high schools namely; MSU-Integrated Laboratory School; MSU-University Training Center (Main Campus); and MSU- University Training Center (Experimental). Marawi City, is the capital of Lanao del Sur located in Mindanao, and the only "Islamic City" in the Philippines.

The Meranaos are the biggest group of Muslims living in the region. There were a total of 145 teachers who served as participants of this study. The researcher adopted the Organizational Climate Description Questionnaire - Rutgers Secondary (OCDQ-RS) developed by Hoy (2003) to describe the MSU feeder high school climate. On the other hand, the Organizational Commitment Questionnaire (OCQ) developed by Allen \& Meyer was adopted to describe the organizational commitment of the MSU feeder high school teachers.

Both the OCDQ-RS and OCQ instruments were slightly modified by the researcher to fit in to the setting of the study; and were pilot-tested among the 30 teachers in MSU-Baloi High School located in Baloi, Lanao del Norte, Philippines. The reliability values for the different dimensions of school climate were as follows: supportive principal behavior (0.91); engaged teacher behavior (0.84); frustrated teacher behavior (0.83); and intimate teacher behavior (0.78). The overall reliability statistics of the school climate instrument is 0.84 which indicated a high degree of reliability. Moreover, the reliability values for the different dimensions of organizational commitment were as follows: affective commitment (0.92); continuance commitment (0.81); and normative commitment $(0.89)$. The overall reliability statistics of the organizational commitment instrument is 0.87 which indicated a high degree of reliability.

\section{RESULTS AND DISCUSSION}

Table 1 presents the MSU feeder high school teachers' assessment on the degree of openness of their school climate in terms of supportive principal behavior; engaged teacher behavior, frustrated teacher behavior, and intimate teacher behavior. The findings revealed that the dominant characteristics of a supportive principal behavior are evident in the MSU feeder high schools. As school administrators, their principals showed desirable behaviors that help create their schools as conducive learning environments. They motivate teachers by using constructive criticisms and setting as good role models through hard work and dedication in their profession. This was confirmed by one of the participants during the focus group discussion when she said that: "Actually I can say we have a positive school climate because we can feel the support of the school head, he sees and appreciates our effort. In that way, we are also encouraged to provide good services for the students, appreciate our head and feel that we belong to the school". Another participant confirmed that: In terms of being supportive, $100 \%$ supportive. It's a big help. She even encouraged us to pursue graduate studies; and attend seminars for our promotion. In terms of criticism, yes, even little mistakes in our paper works, she will immediately give comments, but in a positive way".

These findings are in agreement to the ideas of Smith (2009); Hoy \& Hannum (1998); and Hoy and Clover (1986) when they emphasized that supportive principal behavior is evident among principals who use constructive criticism; compliments teachers; listens to and accepts teachers' suggestions. This confirmed the idea of Hoy and Tarter (1992) when they said that an open or healthy school is one in which the administration is dynamic, supportive, and sets high attainable objectives; and also confirmed the findings of John and Taylor (1999) stressing that a highly open climate is characterized by high trust and consideration of the principal; and the result of a family atmosphere and supportive leadership in the organization.

Table 1 also revealed that the dominant characteristics of an engaged teacher behavior are evident in the MSU feeder high schools. Engaged teacher behavior is reflected by high faculty morale. This behavior is evident among teachers who are supportive of their colleagues; enthusiastic; helpful to each other; accepting and mutually respectful of colleagues' professional efficiency. This was confirmed by one of the participants during the focus group discussion when she said: "Your co-teachers matter. Those who are giving their best for their students even doing things beyond their duties and responsibilities can also motivate other teachers to do the same". The findings confirmed the idea of Smith (2009) when he emphasized that open school climate is evident in engaged teacher behavior characterized by respect for colleague competence, commitment to students, autonomous judgment, and mutual cooperation and support. 
Table 1

MSU Feeder High School Climate's Degree of Openness

\begin{tabular}{|l|c|c|l|}
\hline \multicolumn{1}{|c|}{ School Climate } & Mean & $\begin{array}{c}\text { Standard } \\
\text { Deviation }\end{array}$ & \multicolumn{1}{c|}{ Qualifying Statement } \\
\hline Supportive Principal Behavior & 3.95 & 0.69 & High degree of openness \\
\hline Engaged Teacher Behavior & 4.56 & 0.45 & Very high degree of openness \\
\hline Frustrated Teacher Behavior & 3.96 & 0.61 & Low degree of openness \\
\hline Intimate Teacher Behavior & 4.35 & 0.38 & Very high degree of openness \\
\hline Overall & 4.20 & 0.53 & Very high degree of openness \\
\hline
\end{tabular}

Moreover, Table 1 revealed that the dominant characteristics of a frustrated teacher behavior are not evident in the MSU feeder high schools. Frustrated teacher behavior is characterized by teachers who are overburdened with routine duties, administrative paperwork, and are assigned with nonteaching duties that are excessive. Moreover, frustrated teacher behavior results in divisive and uncommitted teachers (Hoy and Miskel, 1991); and who are often negative and critical about their colleagues and the school (Douglas, 2010).This psychological condition might feed back to teachers alternating moods of hostility and indifference among students (DiPaola and Hoy, 2008). In order to maintain an educational focus, teachers must be able to perform their jobs without undue interference (Hoy \& Hannum, 1998).

Table 1 also shows that the dominant characteristics of an intimate teacher behavior are evident in the MSU feeder high school. Intimate teacher behavior reflects a strong and cohesive network of social relationships among all the teachers in school. This desirable behavior is reflected among teachers who value the quality of their interpersonal relationship with peers and superiors. The findings indicate that the MSU feeder high school teachers have a high sense of camaraderie and belongingness that encouraged them to become more diligent in doing their respective duties. This is confirmed in the responses of the teachers in the focus group discussion when they said that: "we are intimate because we've known each other". Another participant claimed that: "sometimes we eat lunch in our co-teacher's house, We have very close relationship with each other". The findings might also be justified by the cultural orientation of the teachers in MSU feeder high schools. Majority of the teachers are Meranaos. Meranaos are clannish, and so are bound together by feelings of very close associations among themselves and their family members, both near and extended, and even among their closely allied associates.

Table 2 presents the MSU feeder high school teachers' organizational commitment. The findings revealed that the dominant characteristics of teachers with affective commitment towards the schools they are teaching are evident among them. Allen and Meyer (1990) describes affective or emotional attachment to the organization as one that reflects commitment based on emotional ties that teachers develop with the school primarily via positive work experiences. Hence, affective commitment of teachers is exhibited by their strong dedication to stay in the profession and their willingness to do beyond what is required of their profession.

As emphasized by Beck and Wilson (2000) teachers with a high level of affective commitment enjoy their relationship with the school and are likely to stay because they view their personal employment relationship as congruent to the school's goals and values. Their employment in MSU gave them a sense of pride and belongingness that motivated them to stay in their profession. This is confirmed by the response of one teacher during the focus group discussion when she said that: "actually, you will feel proud when someone will ask you where you are teaching, and when you said, I teach in MSU, and that person will say, oh, good on you, you will feel a sense of pride".

Table 2

MSU Feeder High School Teachers' Organizational Commitment

\begin{tabular}{|l|c|c|l|}
\hline Organizational Commitment & Mean & $\begin{array}{c}\text { Standard } \\
\text { Deviation }\end{array}$ & \multicolumn{1}{|c|}{ Qualifying Statement } \\
\hline $\begin{array}{l}\text { Affective Organizational } \\
\text { Commitment }\end{array}$ & 4.58 & 0.44 & At all times committed \\
\hline $\begin{array}{l}\text { Continuance Organizational } \\
\text { Commitment }\end{array}$ & 3.69 & 0.91 & Most all times committed \\
\hline $\begin{array}{l}\text { Normative Organizational } \\
\text { Commitment }\end{array}$ & 3.80 & 0.76 & Most all times committed \\
\hline Overall & 4.05 & 0.70 & Most all times committed \\
\hline
\end{tabular}

Although, teachers admitted that sometimes, they are tempted to be absent, and lazy in doing their job because of some reasons; however, they would feel guilty if they will not report to their respective classes, knowing that their students are waiting for them. This is confirmed by the response of one teacher during the focus group discussion when he said that: "your conscience is your enemy. If you're really committed, you will feel guilty if you just be absent from your classes without any reason. You will feel guilty to your student, to other people, what might they say about you".

The findings might also be justified by the religious orientation of the teachers in MSU feeder high schools. Based on their religion "Islam", their salary could not be considered "Halal" if they have not 
really worked hard for it. This was confirmed by the responses of the participants during the focus group discussion when they said that: "You have to stay 8 hours a day because you have to think that your salary is Halal". Halal", is an Arabic term that refers to any object or action which is permissible to use or engage in, according to Islamic law. The term covers and designates not only food and drink but also all matters of daily life. Thus, "Halal" is anything that is legal or lawful for Muslims.

Moreover, Table 2 revealed that the dominant characteristics of teachers with continuance commitment towards the schools they are teaching are evident among them. Butucha (2013) describes continuance commitment as the extent to which teachers believed that they must remain in the teaching profession because of possible disruptions resulting from leaving their jobs. As emphasized by Rusbult \& Farrell, 1983) teachers with continuance commitment choose to remain with a school largely out of need either due to lack of other work alternatives or lost income, seniority or retirement benefits. Hence, the fewer viable alternatives teachers believe are available; the stronger will be their continuance commitment to their current school. This was confirmed by the responses of the participants in the focus group discussion when they said that: "we cannot avoid to think that of we will leave MSU, where are we going to find another work? We continue to work in MSU because this is our bread and butter".

The findings revealed that the MSU feeder high school teachers are committed to stay in their job basically for economic and personal reasons. As emphasized by Meyer., Stanley., Herscovitch, and Topolnytsky (2002), when teachers decide to remain with their school because of economic reasons; such decision can become an issue for schools as teachers who are continuance committed may become dissatisfied and disengaged with their work and yet, are unwilling to leave their occupation. Teachers who continue to work only out of need may potentially contaminate the work group.

Furthermore, Table 2 revealed that the dominant characteristics of teachers with normative commitment towards the schools they are teaching are evident among them. Meyer and Allen (1991) describe normative commitment as one that reflects among teachers a sense of moral obligation and loyalty to the teaching profession. This was confirmed by the responses of the participants in the focus group discussion when they said that: "of course if we were to base on students, they really need committed teachers, most especially in this place, we pity the students. That is our strong reason to stay in MSU, for the sake of our students. As possible, we don't look at the failures of our school officials". The findings can also be justified by the religious orientation of the teachers in MSU feeder high schools. As followers of Islam, teachers believed that it's their responsibility to reach out to their community people through education. Working to help others, also known as social service, is an Islamic obligation. Hence, teaching is not only considered a profession among the Muslims, but also their way of giving service to humanity.

Table 3 showed the correlation between school climate and organizational commitment of MSU Feeder High School teachers. As shown, there is a positive significant relationship between supportive principal behavior and organizational commitment. This means that the more supportive are the principals, the more committed teachers would become. This confirmed the study of Turan (1998) showing the same positive significant relationship between supportive principal behavior and teachers' organizational commitment. The findings also justify the claims of LaMastro (1999) when he said that administrators who take steps to support their employees and effectively communicate that support reap the benefits of teachers who are strongly committed to their profession; and who are willing to "go the extra mile" for their students and their schools.

The findings also revealed a positive significant correlation between engaged teacher behavior and organizational commitment. This means that the more engaged are the teachers' behavior, the more committed teachers would become. Based on the study of M.A.I. Baig, C.A. Rehman, M.K. Khan (2012), teachers who are highly committed to their schools go beyond their standard role requirement. This is in agreement with Butucha (2013), when he stressed that professionally committed teachers assist students in their extra time; cooperate with and willing to work with parents; and utilize class time profitably. Hence, teachers with engaged behavior will manifest a strong commitment of providing quality education to their students; and in maintaining wholesome relationship with their peers and superiors. This in return will help create schools as conducive and effective learning environments for their students.

Table 3

Correlation between School Climate and Organizational Commitment

\begin{tabular}{|c|c|c|c|c|c|}
\hline \multirow{2}{*}{$\begin{array}{l}\text { School Climate (Pearson- } \\
\text { Correlation values) }\end{array}$} & \multicolumn{5}{|c|}{$\begin{array}{l}\text { Organizational Commitment } \\
\text { (Pearson Correlation-values) }\end{array}$} \\
\hline & Affective & Continuance & Normative & Overall & Remarks \\
\hline Supportive Principal Behavior & $0.439 * *$ & $0.398 * *$ & $0.443 * *$ & $0.487 * *$ & Significant \\
\hline Engaged Teacher Behavior & $0.508 * *$ & $0.491 * *$ & $0.432 * *$ & $0.547 * *$ & Significant \\
\hline Frustrated Teacher Behavior & $-0.332 * *$ & $-0.533 * *$ & $-0.451 * *$ & $-0.533 * *$ & Significant \\
\hline Intimate Teacher Behavior & 0.053 & -0.123 & -0.021 & -0.057 & Not Significant \\
\hline Overall & $0.299 * *$ & 0.119 & 0.197* & 0.213* & Significant \\
\hline
\end{tabular}


Furthermore, the findings showed a negative significant correlation between frustrated teacher behavior and organizational commitment. This means that the less frustrated are the teachers' behavior, the more committed teachers would become. The findings are in agreement with the study of Turan (1998) showing the same negative significant relationship between frustrated teacher behavior and the teachers' organizational commitment. Based on the findings of the study, MSU feeder high school teachers do not have frustrated behaviors resulting from highly demanding superiors; too much work pressure; and indifference of colleagues. Based on the findings of Ololube (2005), providing psychic rewards such as acknowledgement of teaching competence; participatory decision-making; positive feedback; administrative support; reasonable work load; and adequate resources promote teachers' psychological well-being and optimal performance. However, teachers may become unhappy and frustrated if their environment does not afford these kinds of experiences.

On the other hand, findings showed a not significant correlation between intimate teacher behavior and organizational commitment. This indicates that intimate teacher behavior is not a factor to organizational commitment. Based on the findings of the study, MSU feeder high school teachers know each other well; are close personal friends, and regularly socialize together; however, this desirable behavior among teachers is not a guarantee of their commitment to the organization.

Overall, the findings showed a positive significant correlation between school climate and organizational commitment of MSU feeder high school teachers. This finding is in agreement with the study of Douglas (2010) and Raheem (2009) which showed also a positive significant relationship between school climate and teacher commitment. Hence, there is strong evidence that school climate influence teacher commitment. Thus, school administrators must give their best effort of creating a positive school climate; a climate of encouragement and professionalism that will empower their teachers; making them the most valuable assets of the school. The success of the school in attaining their mission, vision and objectives lies on the hand of dedicated, loyal, and committed teachers.

\section{CONCLUSION}

The following conclusions are drawn based on the findings of the study: The MSU feeder high schools have high degree of openness on school climate in terms of supportive principal behavior. Moreover, these schools have a very high degree of openness on school climate in terms of engaged and intimate teacher behavior. However, MSU feeder high schools have low degree of openness on school climate in terms of frustrated teacher behavior.

On the other hand, MSU feeder high school teachers are all of the times committed to their organization in terms of affective commitment. They are most of the times committed to their organization in terms of continuance and normative commitment. It is concluded that school climate affects the organizational commitment of MSU feeder high school teachers.

\section{ACKNOWLEDGMENT}

L.A.B. is grateful to her family, the Mindanao State University-Marawi City, Bukidnon State University and to her Almighty God.

\section{REFERENCES}

[1] Abdul-Raheem, M. A. 2009). The Level of Commitment and its Relation to Students' Achievement as Perceived By English Language Teachers in Public Schools in Tulkarm District. Thesis. An-Najah National University, Nablus, Palestine.

[2] Allen, N., and Meyer, J. 1990. The Measurement and Antecedents of Affective, Continuance, and Normative Commitment to the Organization, Journal of Occupational Psychology, Vol. 63, 1-18.

[3] Baig, M. A. I., Khan, M. K., and Rehman, C. A. 2012). A Study of the Relationship of Organizational Commitment with Participation in Decision Making, Procedural Justice And Organizational Citizenship Behavior in Teachers of Not-for profit Schools of Lahore, Pakistan. Journal of Quality and Technology Management, VIII(2), 25-49.

[4] Beck, N., and Wilson, J. 2000. Development of Affective Organizational Commitment: A CrossSequential Examination of Change with Tenure. Journal of Vocational Behaviour, 56, 114-136.

[5] Butucha, K. 2013. Teachers' Perceived Commitment as Measured by Age, Gender and School Type. Greener Journal of Educational Research, 3(8), 363-372.

[6] DiPaola, M. F., \& Hoy, W. K. 2008. Principals Improving Instruction: Supervision, Evaluation, and Professional Development. Boston: Pearson/Allyn \& Bacon.

[7] Douglas, S. M. 2010. Organizational Climate and Teacher Commitment. Dissertation. University of Alabama, Tuscaloosa. Alabama.

[8] Gruenert, S. 2008. School Culture: They Are Not The Same. Alexandria: National Association of Elementary School Principal.

[9] Hoy, W. K. 2003. An Analysis of Enabling and Mindful School Structures: Some Theoretical, Research, and Practical Consideration. Journal of Educational Administration, 41, 87-108.

[10] Hoy, W. K., \& Clover, S. I. R. 1986. Elementary Climate: A Revision of the OCDQ. Educational Administration Quarterly, 22(1), 93-100.

[11] Hoy, W. K., \& Hannum, J. 1998. Middle School Climate: An Empirical Assessment of organizational health and student achievement. Educational Administration Quarterly, 33, 290-311.

[12] Hoy, W. K., and Miskel, C. G. 1991. Educational Administration: Theory, Research and Practice. New York: McGraw Hill, Inc.

[13] Hoy, W. K., \& Sabo, D. J. 1998. Quality Middle Schools. Thousand Oaks, CA: Sage.

[14] Hoy, W. K., and Tarter, C. J. 1992. Measuring the School Climate: A Conceptual Framework. NASSP Bulletin, 76(547), 74-79.

[15] John, M., and Taylor, J. 1999. Leadership Style, School Climate, Leadership and the Institutional Commitment of Teachers. International Forum, 2,(1) 25-57. 
[16] LaMastro, V. 1999. Commitment And Perceived Organizational Support. National Forum Of Applied Educational Research Journal, 12(3).

[17] Meyer, J. P., \& Allen, N. J. 1991. A Three Component Conceptualization of Organizational Commitment. Human Resource Management Review, 1, 61-89.

[18] Meyer, J. P., Stanley, D. J., Herscovitch, L., and Topolnytsky, L. 2002. Affective, Continuance and Normative Commitment to the Organization: A Metaanalysis of Antecedents, Correlates, and Consequences. Journal of Vocational Behavior, 61, 20-52.

[19] Ololube, P. N. 2005. Teachers Job Satisfaction and Motivation for School Effectiveness: An Assessment. Dissertation. University of Helsinki Finland.

[20] Razak, A., Darmawan, I., and Keeves, J. 2009. Teacher Commitment: Teachers Handbook of Research on Teachers and Teaching, 343-360.

[21] Rusbult, C. E., \& Farrell, D. 1983. A Longitudinal Test of the Investment Model: The Impact on Job Satisfaction, Job Commitment, and Turnover of Variations in Rewards, Costs, Alternatives, and Investments. Journal of Applied Psychology, 68, 42938.

[22] Smith, L. D. 2009. School Climate and Teacher Commitment. Dissertation. The University of Alabama, Tuscaloosa, Alabama.

[23] Turan, S. 1998. Measuring Organizational Climate and Organizational Commitment in the Turkish Educational Context. Paper Presented at the Annual Meeting of the University Council for Educational Administration. St. Louis, MO. 